\title{
Deleuze's Reversal of Platonism: Focus on his CRITICisM OF ANÁMNESIS
}

\author{
[ Deleuze e AReVERSÃo do Platonismo: Notas sobre a Crítica À ANAMNeSe ]
}

\author{
Valeria Sonna Correio * \\ Universidad Nacional de San Martín (UNSAM), Argentina
}

\begin{abstract}
Gilles Deleuze's critical reception of Plato's philosophy is developed under the formula of its reversal, the task Nietzsche entrusted future philosophy with. But what does this reversal mean? Deleuze's reversal of Platonism has been widely discussed. Most of the studies focus mainly on "Platon et le simulacre", where Deleuze characterizes reversal on the basis of the concept of simulacrum, and his further elaboration in Difference and repetition. An aspect of reversal that has not been considered so far is Deleuze's reversal of the Platonic image of thought, which is expressed through his critical reading of Plato's theory of anámnesis. In our paper we show that this criticism is a fundamental core of the task of reversal.
\end{abstract}

KEYwORDS: Deleuze; Plato; Recollection; Difference and repetition; Image of thought
RESUmo: A recepção crítica de Gilles Deleuze da filosofia de Platão é desenvolvida sob a fórmula de sua reversão, a tarefa com a qual Nietzsche confiou a filosofia futura. Mas o que essa inversão significa? A inversão de Deleuze do platonismo tem sido amplamente discutida. A maioria dos estudos se concentra principalmente em "Platon et le simulacre", onde Deleuze caracteriza a reversão com base no conceito de simulacro, e sua posterior elaboração em Diferença e repetição. Um aspecto da reversão que não foi considerado até agora é a inversão de Deleuze da imagem platônica do pensamento, que é expressa através de sua leitura crítica da teoria da anámnesis de Platão. Em nosso artigo, mostramos que essa crítica é um núcleo fundamental da tarefa de reversão.

Palavras-chave: Deleuze; Platão; reminiscência; Diferença e Repetição; Imagem do pensamento

\section{INTRODUCTION}

$G_{\text {the formula of its reversal, the task Nietzsche entrusted future philosophy }}^{\text {illes Deleuze's critical reception of Plato's philosophy is developed under }}$ with. But what does this reversal mean? This topic has been widely discussed. It has often been emphasized that the role that Plato plays in his work, as Deleuze himself puts it, is an ambiguous one. His strategy in "Platon et le simulacre" is to find reversal inside Plato's own philosophy (Deleuze, 1969: 292-295) and in Différence et répétition he explicitly states that it is not only inevitable but also desirable that reversal preserves a lot of platonic elements (Deleuze, 1968: 82).

* Philosophy Doctor at Universidad de Buenos Aires (UBA). Faculty Member at Universidad Nacional de San Martín (UNSAM) and at Universidad de Ciencias Empresariales y Sociales (UCES). Special thanks to a Postdoctoral Scholarship by the National Research Council of Argentine.m@ilto:vsonna@gmail.com 
According to Wolff (1992) Plato is an unstable figure in Deleuze's work because he introduces and at the same time breaks the conceptual oppositions Deleuze sets to disarticulate. Wolff finds that Deleuze shares Derrida's and Foucault's intention as historians of Platonism, that is, to find in Plato the first chapter of a philosophical narrative that we could call the "history of metaphysics". Consequently, they share a procedure by means of which they follow the trail of this major event in the platonic source: to scrutiny the pages in search for a phrase, a sign that betrays the birth of that will to truth that takes the name of "Platonism". But, according to Wolff, Deleuze is not as suspicious as his colleagues, because he still reads the dialogues as bearers of acceptable statements, not only as significant in virtue of their symptomatic meaning. (p. 169).

Ginoux, (2005) refers to the ambiguity of Plato's role in deleuzian philosophy as a phármakon that constitutes the venom as well as the remedy to the decade of representative thinking. She stresses that unlike the role that Plato plays in Nietzsche's philosophy, which is mainly negative, in Deleuze's work Plato has a double face (p. 156-157). As Ginoux points out, there is a profound influence of Plato in Deleuze's work. It is from the Platonic source, mainly the Sophist, that Deleuze extracts the initial outline of the subordination of difference to the four fundamental instances of representation (identity, likeness, opposition and analogy) in Différence et répétition. Moreover, in Logique du sens, Deleuze takes Plato's image of the sage as the paradigm of the classic philosopher that influenced the conception of what a philosopher is in the tradition of Idealism (Deleuze, 1969: 152). Also, in this same text, he puts forward the Platonic philosophy as the paradigm of classic philosophy that gets reverted by the Stoics for the first time history (1969: 34). ${ }^{1}$ In Anti-OEdipe, a book in which the main objective is the critique of some key concepts of psychoanalysis, Deleuze and Guattari trace the inaugural moment of the conception of desire as a shortage (manque) to Plato (1972:32-33) and in Qu'est-ce que la philosophie, they locate Platonism at the inflection point in which philosophy subordinates the plan d'immanence that the Presocratics traced to the transcendence of a universal concept (the One, the Whole, the Idea of Good).

Taking upon Ginoux's and Wolff's statements about the ambiguous role that Plato plays in Deleuze's philosophy, my purpose in this paper is to look into those elements of Platonism that are worth keeping. Even though it has been well explained that Deleuze does not overthrow the entire corpus of Plato's philosophy, the question of which elements of Platonism he preserves is still open. Most of the studies focus mainly on "Platon et le simulacre", where Deleuze characterizes reversal on the basis of the concept of simulacrum, and his further elaboration in Difference and repetition. ${ }^{2}$ (Alliez, 1992; Williams, 2003; Smith, 2006; De Beistegui, 2010; Heredia Ríos, 2011) But an aspect of reversal that has not been fully considered so far is Deleuze's reversal of the Platonic image of thought as expressed through his critical reading of Plato's theory of anámnesis. In the present paper I intend to show (a) that this criticism is a fundamental core of the task of reversal and (b) that the element worth keeping, besides the concept of simulacrum, is Plato's construction of what Deleuze calls the object of encounter, which, ironically, presents an alternative to the object of recollection.

My exposition is divided in three sections. The first one focuses in the ambiguity of Platonism as Deleuze as expressed by Deleuze's use of the platonic concept of simulacrum. In Différence et répétition Deleuze presents the reversal of Platonism in the first chapter of this book, where he explains the logic and ontology of difference according to Plato's method of division. To a great extent, this text is an expanded version of what is stated in Platon et le simulacre, but it introduces an interesting 
criticism to Plato's anámnesis as part of a broader critical reading of Plato's philosophy as a figure of the dogmatic image of thought. Strictly speaking, in this text Deleuze stresses the ambiguity of the role of Plato's philosophy not in the first chapter, in relation to the concept of simulacrum, but in the third chapter, in relation to the role that anámnesis plays in the dogmatic image of thought. The second section is therefore focused on this connection between Plato's recollection theory and the epistemic model of recognition, which constitutes the fourth postulate of the dogmatic image of thought that Deleuze sets to overthrow. Recognition is defined by the concordance of the faculties upon an object that is supposed to be the same for every one of them. It is the same object that can be touched, seen, remembered, imagined, conceived, etc. Thought is supposed to be the unity of all these faculties and its epistemic correlate is the "object of recognition". In the third section I will address the opposition between the "object of encounter", which constitutes the genesis of thought according to Deleuze and the "object of recognition". I will try to show that the relevance of the Deleuzian reversal lies in the fact that he elaborates the notion of the object of encounter from within the Platonic source.

\section{THE REVERSAL AND THE SIMULACRUM}

The main concept of Deleuze's reversal is the simulacrum. This concept has attracted the attention of most scholars, even though it is a concept that Deleuze himself later dismissed as "not worth much" (Deleuze, 2003, p. 339). In this letter to Jean-Clet Martin, he affirms that the concept of rhizome expresses multiplicity far better than the concept of simulacrum (idem). Non-the less, it is by means of the simulacrum that Deleuze unveils the multiplicity behind the platonic Idea.

It is agreed among scholars that the essential aspect of reversal is the claim that identity cannot be the foundation of selection, which is a consequence of the disruption of representation by the simulacrum. It has been noted that the methodology unfolded in Deleuze's interpretation of simulacrum consists of a symptomatological reading. This means that Deleuze's interpretation of Plato's statements focuses on the results of the forces expressed in the text beyond the logic of the author function (Alliez, 1992: 157). Deleuze digs up a hidden Plato: given a concept such as the simulacrum we must take it as a symptom. And the question we must ask is "what is it a symptom of"? Deleuze's diagnosis is: it is a symptom of a will to select. This is the way in which the will to power expresses itself in Plato's work. The will to select is the motivation that hides within the theory of Ideas and it needs to be brought out to light in order to reverse Platonism.

It has also been noted that Deleuze's reversal must be read not only as an objection to Platonism, but as a rejuvenated Platonism in which the concept of simulacrum introduces a new conception of Platonic Idea, not as identical (autó kath'hautó), but as immanent and differential. According to Smith (2006), this gives a new meaning to selection, repetition and un-grounding (pp. 19-26). ${ }^{3}$ Smith states that Deleuze's reversal has three main premises. The first one is the claim that, unlike the copy, the simulacrum is an image without resemblance; the second one states that if the simulacrum is an image without resemblance, it is because the Idea itself no longer has the identity of a self-same model, but rather is now constituted by difference-in-itself; and the third one states that the mode under which this disparity or difference is apprehended is a problematic mode since there is no longer place for truth and falsity and, consequently, for 
mistake. According to Smith, this unleashes the power of pseûdos (falsehood): "truth" now becomes an affirmation of the simulacrum itself, falsity (art) affirmed and raised to a higher power" (2006, p. 16). The deceitful character of the simulacrum is a constituent element of the platonic use of this concept. In Deleuze's reading, this deceitful trait, combined with the absence of a Model (the simulacrum does not follow the Idea as parádeigma) affirms the puissance of the simulacrum: the power of pseûdos that reveals the Idea as obsolete.

De Beistegui (2012) restores the importance of the development of the concept of simulacrum and Deleuze's project of reversal in the light of the lineament of his later work, namely, how to think and live without transcendence. According to him Deleuze reverses the terms of the problem posed by Plato, i.e., how to select copies among simulacra, in order to reveal that it is possible to think images outside the framework of representation, in order to produce an image of thought that is based on a different thought of the image (2012: 77). De Beistegui focuses on another trait of the simulacrum, namely, it's immanence. In the Sophist, Plato explains the operation behind the thaumatic ${ }^{4}$ effect of the simulacrum with a very eloquent example. While the copy respects the proportion relations provided by the model, the simulacrum doesn't, for it is built very much like the way a sculptor builds a big scale monument (Sof. 235d236a). An example of how these sculptors proceed is the Epicurean inscription of the wall of Oenoanda, where the letters inscribed in the superior lines are larger than the inferior ones so that the text is presented as homogeneous and proportionate to the observer that stands on the floor. Deleuze's interpretation follows Xavier Audouard, who accurately reads this as an expression of the immanent character of these images, where the observer is part of the referential system, much like the role of the observer in Mach's principle. This is why he understands that the main problem behind Plato's simulacrum is the problem of the Subject as foundation of phaenomena (Audouard, 1966).

I agree with these readings on the fact that the simulacrum serves the purpose of showing the idle character of Forms as metaphysical foundation of knowledge and being. But I think that this is exactly the purpose that the simulacrum serves in the Sophist and, therefore, this is not a proper critique against Plato. At least not the Plato of the last period, who by the time that he wrote this dialogue, had already exposed the limitations of Forms and of the concept of participation in the Parmenides. ${ }^{5}$ The distinction between Plato's middle dialogues and his last dialogues, among which we can find the Sophist, is, however, not considered by Deleuze's critique.

Deleuze accurately puts forward the power of the combination of myth and dialectics. He also accurately demonstrates that this distinction ceases to be valid when the dialectic discovers in the division its true method: on the one hand, division needs myth as the foundation that produces difference and the myth needs division as the state of difference in that which is founded. Forms operate as criteria for selection in the area already distributed by myth and division. The way in which the Idea operates is clearly seen in the Platonic notion of "participation" (méthexis). The platonic concept of méthexis comes from the verb metékho ("to have part of" or "to take part in"). According to Deleuze the structure of participation is a threefold one: the essence of the foundation gives some quality or property in participation to the participant, that Deleuze calls the "suitor". The fair suitor is the authentic, the well-founded pretender, the copy or icon, while the ill-founded suitors are his fakes, his simulacra. Such is, for example, the case of the sophist who is the jester, the satyr of the philosopher. If we follow Deleuze's interpretation, the subtext in Plato's logos is that the role of the Form is not, as he holds, to found the selection, but actually to denounce these falsifications. 
This interpretation is incisive because it reveals the motivation behind the Platonic concept of Form. It is, moreover, original, because it finds an articulation between the method of division, the dialectic and the use of the myth that is totally novel and describes very well the general purpose of the Plato of the middle dialogues. Especially if one considers the struggle of Plato against relativism presented as a struggle against sophistry (and sometimes against Heraclitism). However, the scheme by which Deleuze describes the Platonic machinery mixes two moments of his philosophy that must be properly differentiated since they do not describe the same use of the concept of Form. This is important because his criticism points to the notion of participation and to the concept of Form that is subsidiary to it. These two concepts, as well as the theory of anámnesis that completes the gnoseological system of the middle dialogues are discarded by Plato in the period of old age. The gnoseology of the middle dialogues relies upon the theory of recollection that guarantees the human access to the noetic, identified with the divine. Human knowledge, while defective with respect to the divine, nevertheless is capable of accessing divine truths. The late epistemology, on the contrary, renounces this way of thinking the Forms. The notion of méthexis, that explained the relation of phenomena to the Forms, is replaced by the notions of koinonia (communication) and of symploké (combination) (Sof. 248a), which are links between Ideas, but not between Ideas and the sensible. In the Sophist, the Forms are not the ontological criteria for empirical individuals. They combine and communicate among them and with the mégista géne, determining the realm of the combinations that lógos admits. The task of the dialectician is to know and master those combinations (Sof. 249d-254d). ${ }^{6}$ With this in mind, we can assume that it is most likely that the irony that Deleuze attributes to the Sophist was intended. Indeed, the entire search for a definition of sophistry is but an ironic attempt that ends up in a playful definition (Sof. 268d)

\section{Deleuze Critical reading of Plato's theory of anámnesis}

As I said before, there is an aspect of reversal that is systematically omitted by the comments on reversal even though it is, I believe, a fundamental core of the subject. As it has been well noticed, Deleuze presents the reversal of Platonism in the first chapter of Différence et répétition, where he explains the logic and ontology of difference according to Plato's method of division. To a large degree, this text is an expanded version of what is stated in Platon et le simulacre, but Deleuze introduces an interesting reflection on the role of anámnesis that is absent in the latter and that will be resumed in the third chapter. This contains, I believe, another aspect of reversal. Here, Deleuze affirms that Plato's gnoseology is functional to the fourth postulate of the dogmatic image of thought, the model of recognition, and that anámnesis works as a repentance (Deleuze, 1968, pp. 184-192).

The main argument Deleuze directs against anámnesis is that the appeal to the immortality of the soul, as well as the idea that knowledge exists before it is recollected reduces knowledge to a mere recognition of preexisting meanings (1968: 185). In Deleuze's view, knowledge and, more accurately, the process of thinking, consist in the creation of meaning. This is why in my opinion Deleuze's critique of Plato's recollection theory directs against Plato the same argument Socrates directs against Meno in the homonymous dialogue. Namely, that his description of knowledge renders us indolent.

Despite the strength of this objection, Deleuze recovers the value of two aspects 
of anámnesis. The first one is the attempt of including time into the process of thinking, even though it is a mythical conception of time, which brings down the original attempt. The second one is the idea that there is an opacity that is intrinsic to the process of thinking. Non-the less, these attempts become obsolete with Plato's appeal to the transcendent character of knowledge.

In the first place, Deleuze objects that the correlate of recollection is always an intelligible object, which renders idle the appeal to the senses. According to Deleuze, the object of recollection should not be called intelligible, for this term expresses a modality of the object. Tacitly, this implies that it could also also be perceived by the senses, but, strictly speaking, the object of anámnesis can only be apprehended by the intellect: it is a noetós, pure essence. According to Deleuze, the object of recollection should be called the being of the intelligible itself, because this expression refers literally to "that which can only be apprehended by the intellect" (1968: 182-3). The problem is that Plato himself appeals to sense perception as the first instance of our apprehension of the object of anámnesis when it actually has no way to apprehend it. Therefore, he installs a dislocation at the heart of the learning process.

In the Phaedo remembrance is described as an intuition. The term is ennoéo ("to have in the mind"), a sort of understanding (73d). The kind of knowledge that recollection accounts for is a special type of knowledge that Plato expresses with the term paragignomai ("to come up", or "to appear to mind", although it also means "to help", a connotation that is not absent in Plato's reconstruction of recollection). Plato gives a few examples to explain this intuition. From these examples there is one that is especially useful in order to understand Deleuze's critique, it is the example of the wooden logs. In this section of the dialogue Plato states that similar objects are similar in virtue of their participation of the Form of Equality (autò tò ison). The reason is that the imperfection of the equality sensed between equal objects always fails with respect to the Idea of the perfect equality. The Form of Equality is in itself (autós) and is therefore different from the equality perceived by the senses and from the equal objects. Therefore it stands as something separate and transcendent that determines and shapes the sensible experience. Plato's argument states that if we perceive two objects as similar, given that they present differences as much as similarities, this means that there is something in our soul that shapes these objects as similar, and this is the Form of Equality (74b-c). This means that in addition to being separate and transcendent, the Form of Equality is epistemologically prior to sense perception. This is intended to explain a general trait of the way we think. ${ }^{7}$

If the argument stopped at this point, Plato would be a mere idealist and wouldn't draw Deleuze's attention. The interesting turn is that in addition to the description of the process by which we perceive equal objects, Plato is concerned with describing the way we develop the knowledge of the existence of such a thing as the Form of Equality, and in this process, the sense perception of equal things is an unavoidable part of the process. This supposes a double reading of recollection, one directed to the general public and another one directed exclusively to those whose intention is to grasp the Forms. While the prior process of recollection is available to everyone, the process of knowledge of the Forms is directed to the initiated public. To those who, just as Socrates's interlocutors in the Phaedo, are interested in philosophy (see Scott, 1999).

The way in which Plato presents recollection gives senses a crucial role in the process of thought because, unlike Cartesian innatism, recollection needs the senses in order to be triggered and can therefore remain unrealized. But, as Deleuze objects, Plato seems to discard senses once they have played their role, making the object of 
knowledge a pure essence that has no trace of it's empirical origin.

The second objection that Deleuze directs against anámnesis is that Plato confuses the past-being with the being of the past. The mechanism is the same: Plato replaces the empirical past with a mythical one ${ }^{8}$ and erasing al traces of its empirical origin. Empirical memory addresses things that have necessarily been apprehended by other faculties. What I remember, I have seen, touched, understood, imagined or thought before. The anámnesis, however, is directed to an object that from the first time cannot be but remembered. This memory is not of a contingent past, but of the being of the past as such: a past of all times, an absolute past that is not related to a specific present (1968: 183). The time present also becomes absolute and therefore time doesn't really affect it (nor history) or our knowledge of it.

The same can be said about oblivion. In the empirical memory, it is a contingent incapacity that separates us from a given memory. But in recollection it is a power of memory itself, "nth power", that which can only be remembered (1968: 183). Oblivion constitutes the limit of recollection and it's object, at the same time: it is an immemorial memorandum. This scheme hides an implicit statement: that which can only be remembered (the object of absolute oblivion) is also impossible to remember (because it traces the limit of memory).

\section{THE VIOLENCE OF THE GENESIS OF THOUGHT}

Deleuze suggests that, pace Plato's theory of anámnesis, Plato's dialogues portray the act of thinking not as arising from a moment of recognition, but from a fundamental encounter that forces thought to arise. This encounter can be apprehended under different affective tonalities (admiration, love, hate, pain, etc.) but its main characteristic is that it can only be perceived. It cannot be remembered, imagined or conceived. It is not aisthêtón (what can be perceived), but aisthetéon (what cannot be but perceived). What cannot be but perceived is the sign. Every time Deleuze refers to the violence of encounter as the genesis of thought, he traces its origin to Plato (1962:124, 1964:122-124; 1968:181; 1969: 184). He refers a passage in the Republic in which Socrates says that what excites or invites (parakaléo) thinking are those perceptions that produce contradiction (enantian aisthesin), while the things that are easily recognizable, like a finger, do not (Rep. 523b-d).

"Here, I show," I said, "if you can make it out, that some objects of sensation do not summon the intellect to the activity of investigation because they seem to be adequately judged by sense, while others bid it in every way to undertake a consideration because sense seems to produce nothing healthy." $(523 \mathrm{~b})^{9}$

The finger is the paradigm of the object of recognition while the opposed perceptions constitute the violence that forces thinking to arise, the object of encounter. This is, according to Deleuze, the role of signs.

"The ones that don't summon the intellect," I said, "are all those that don't at the same time go over to the opposite sensation. But the ones that do go over I class among those that summon the intellect, when the sensation doesn't reveal one thing any more than its opposite, regardless of whether the object strikes the senses from near or far off. But you will see my meaning more clearly this way: these, we say, would be three fingers-the smallest, the second, and the middle." (523c) ${ }^{10}$

According to Deleuze, even though the idea that the violence of encounter is the origin of thought is traceable to a Platonic source, anámnesis states the exact opposite, i.e., that the origin of thought is the recognition of a stable Form concealed behind or 
wrapped in (envelopée) the perceived object. ${ }^{11}$ This is why it works as a sort of repentance (1968: 185).

As we said, absolute oblivion works as the limit of memory. The problem is that Plato confuses the limit of the faculty with a transcendental, noetic object. The limit of perception is what cannot be perceived either because it is too big or too small, but Plato replaces this limit with a noetic transcendental object that can only be recovered by this absolute memory, extracted from an immemorial past (1968: 181-186).

Deleuze first developed this argument in Proust et les signes, where he puts Proust's reminiscence in contrast with Platonic recollection. A la recherche du temps perdu is the description of a process of learning in which memory plays a central role. While at first sight Proust's conception might seem Platonic - to learn is to remember-, memory is just a tool for him. In Proust's recollection, the process of learning exceeds memory in principle and in its purpose. Proust's recollection is directed to the future, not to the past (1964:10). The objects of this process are the signs, which, as opposed to Platonic Forms, are the object of a concrete sort of knowledge, not an abstract one. Time is part of the empirical process of learning and the past remembered is not an immemorial past.

In Proust's recollection, involuntary memory is triggered by a perception: an old feeling superimposes and connects to the actual feeling and extends it over several periods at the same time. But this superimposition does not imply the absolute recovery of that contingent past. The remembered feeling connects to the actual one and gives place to the ambiguity of that contrast (1964:23). An example is the famous passage of the cupcake. Its flavor mixed with the tea unchains a series of associations: aunt Léonie, Sunday morning at Combray, the joy, the old grey house, the town, etc. (Proust, 1919: 65 ff.).

This recollection is nothing like the Plato's. In Phaedo, recollection consists in the noetic association between two objects. This association is triggered by the perception of one of them, like the cloak and the lyre reminds Cebes of his lover, or Cebes reminds Socrates of Simmias (Phaed. 73d -74a). In Proust's, one perception, in this case the flavor, recalls a feeling, in this case, the joy, which in turn recalls a previous context that connects to the present context and its actual feeling, in this case, anguish.

\section{THE EXOGENETIC CHARACTER OF THOUGHT}

According to Deleuze perception, memory, imagination, intelligence and thought itself can all be performed either voluntarily or involuntarily. Voluntary performance is also contingent given that when we voluntarily perceive something, we can also imagine, remember and conceive it, and the other way around. Only under this condition can we speak of the unity of faculties. Only when they perform harmoniously in the context of the arbitrary and the abstract they meet their truth, which is equally abstract (1964: 123). When violence forces us to think, the faculties perform involuntarily and this entails their necessity. They cease to be interchangeable: each one of them discovers only what it can interpret; each one of them relates to a specific realm of signs.

A fundamental aspect of the Deleuzian image of thought is the discordant use of the faculties. They do not coincide in an object or in a subject (1968: 181-192). In Deleuze's image, thought is exogenetic. This means, firstly, that thought cannot be selffounded, or be the foundation for the intelligibility of the real. Secondly, that the 
conditions of thought are not given within thought, they come from without, from the encounter with the sign. But that does not mean that it is external to the realm of signs. Its conditions come from without, but it is, at the same time, immanent to its object (De Beistegui, 2010: 13).

Thought is not a natural possibility but an act of creation. In any case, what is natural for thought is a state of stupefaction that needs to be shaken from without (1964: 118). And the act of thinking entails a task of interpreting, decoding and translating the plurivocity of sense implicated in the signs. There are no explicit meanings or clear ideas. According to Deleuze, this complexity is insinuated by Plato's use of the aporia of sense perception in Rep. 523b-d and, we may add, in the process of anámnesis in the Meno. Sadly, the object of anámnesis is noetic and that steals away all interference of sense perception or of aporiai in the construction of its object. Thought is thus relegated to a passivity that consists of the mere reception of complete and fully existing meanings, where there is no place for creation, which is thought's defining character according to Deleuze.

\section{Conclusion}

In the introduction to this paper I set myself to the task of showing that Deleuze's critical reading of Plato's theory of anámnesis is a fundamental aspect of the reversal of the dogmatic image of thought. Based on the idea, put forward by Wolff and Ginoux, that Plato's ambiguity in Deleuze's thought amounts to the disarticulation of the metaphysical oppositions that it inaugurates and that Plato's influence is not to be taken merely as a negative one, I proposed a reading based on the positive elements that Deleuze extracts from Plato's work and uses in his own. The simulacrum is one of them, and much has been said about Deleuze's use of this concept. Nonetheless, the concept of the object of encounter expresses, far more eloquently than the simulacrum does, the Heraclitean force that roars in the core of Plato's dialogues since it describes the genesis of thought as an excitement (the term used by Plato is parakaléo) that comes from beyond, form the aporia in which the senses leave us.

Although it is true that the simulacrum serves the purpose of showing the idle character of Forms, both as paradigms and as metaphysical foundation, I tried to argue that Plato himself saw this limit of his conceptual construction. Plato himself presents all the possible objections to the concepts of Forms and participation in the Parmenides, the dialogue that immediately precedes the Sophist that gives Deleuze the basis for his reading of the simulacrum. This dialogue presents a renewed epistemology, based on a different conception of Forms that articulate a far more complex conception of the specificity of philosophical knowledge as the mastering of the correct combination of Forms and genres both in thought and in lógos. As I said, it is most likely that Plato intended the final irony that Deleuze denounces, for this new version of the Forms manages without participation.

On the other hand, there is the concept of the object of encounter, this empirical and violently aporetic genesis of thought that Deleuze highlights. This is Plato's most entangled character: the empirical face that keeps sticking out in the realms of Idealism. It is also a sensible subject among his commentators that cannot come to an agreement as into which role to assign to sense perception in platonic philosophy. There is a simplistic view of the division the platonic gnoseology presents that opposes the sensitive things that are perceived to the intelligible things that are intelligible. A more complex version of this division takes into account the way in which Plato presents his 
epistemology in the later dialogues, that is, as a synthesis between an Eleatic position that requires the statism of the object of the nóesis, and an Heraclitean position that affirms the permanent mobilization of all correlates of perception. These positions require different types of correlates, one for perception, mobile and changing, corruptible; this object becomes (gígnesthai) but it does not properly exist (einai), the other is the object of nôेs, static and permanent, incorruptible; this object properly exists (eînai) and does not become (gígnesthai). This position is the one that becomes manifest in the Theaetetus, where perception is discarded as a form of epistéme because its object does not remain stable. To this way of interpreting the Platonic foundation of the episteme lays the assumption that the theory of ideas is elaborated on the basis of the model of perception (Runciman 1959; Ryle, 1990). ${ }^{12}$ This problem is clear to Deleuze who, however, is not concerned with trying to save Plato from the aporiai raised from this analogy. Deleuze focuses on the epistemic limitations of this model to indicate which are the problems that are presented to Plato as a consequence of his attempt to erect a transcendental plane that is traced from the empirical plane. This truly opens up a gate to it's reversal: is it possible to think another Plato, an empiricist immanent, bodily Plato? In my opinion, it is, and this is the task that Deleuze's project of reversal entrusted future philosophy with.

\section{REFERENCES}

Alliez, Eric, "Ontologie et logographie. La pharmacie, Platon et le simulacre" Nos grecs et leurs modernes (B. Cassin, pp. 211-230). Paris: Éditions du seuil, 1992.

Annas, Julia, An Introduction to Plato's Republic. Oxford: Oxford University Press, 1981.

Audouard, Xavier, "Le Simulacre", Cahiers Pour L'analyse, 3, 57-72, 1966.

Bedu-Addo, "Sense-experience and the Argument for Recollection in Plato's Phaedo". Phronesis, 36(1), 27-60, 1991.

Burnet, John, Plato. Platonis Opera (ed.). Oxford: Oxford University Press, 1903.

De Beistegui, Miguel, "The Deleuzian reversal of Platonism" The Cambridge Companion to Deleuze (D. Smith, H. Somers-Hall, pp. 55-82). Cambridge: Cambridge University Press, 2012.

Deleuze, Gilles, Proust et les signes. Paris: Presses Universitaires France, 1964.

Deleuze, Gilles, Différence et Répétition. Presses Universitaires de France, 1968.

Deleuze, Gilles, Logique du sens. Editions de Minuit, 1969.

Deleuze, Gilles, Deux régimes de fous. Paris: Les éditions de minuit, 2003.

Deleuze, Gilles \& Guattari, Félix, L'Anti-OEdipe. Paris: Les éditions de minuit, 1972.

Ginoux, Isabel (2005). Platon. In Aux sources de la pensé de Gilles Deleuze (S. Leclerc, Vol. 1, pp. 155-160). Paris: Sils Maria Éditions, 2005.

Bloom, Allan (Trans.) Plato. Republic (3 edition). New York: Basic Books, 2016.

Proust, Marcel, A la recherche du temps perdu. Du côté de chez Swann (Vol. 1). Paris: Gallimard, 1919.

Runciman, W. G., Plato's Later Epistemology (1st edition). Cambridge University,1962.

Ryle, Gilbert "Logical Atomism in Plato's Theaetetus." Phronesis, XXXV, 21-46, 1990.

Scott, Dominic "Platonic Recollection." In G. Fine (ed.) Metaphysics and Epistemology (pp. 93-124). Oxford: Oxford University Press, 1999.

Smith, Daniel The concept of the simulacrum: Deleuze and the overturning of Platonism. Continental Philosophy Review, (38), 89-123, 2006.

Williams, James Deleuze's Difference and repetition: a critical introduction and guide. Edinburgh: Edinburgh University Press, 2003.

Wolff, Francis Trios. Deleuze, Derrida, Foucault, historiens du platonisme. In B. Cassin (Comp.) pp. 232-249. Paris: Éditions du seuil, 1992. 